\title{
Detection of bovine herpesvirus 1 and 5 in trigeminal ganglia of beef cattle in Uruguay ${ }^{\#}$
}

\author{
Detección de herpesvirus bovinos 1 y 5 en ganglios trigéminos de bovinos de carne en Uruguay
}

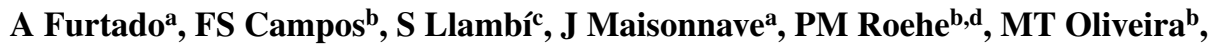 \\ FR Spilkie, AC Franco ${ }^{b}$, R Puentes $^{\mathbf{a}^{*}}$ \\ aDepartment of Microbiological Sciences, Faculty of Veterinary, University of the Oriental Republic of Uruguay, \\ Montevideo, Uruguay.

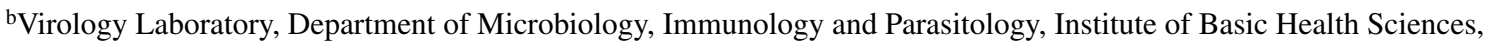 \\ Federal University of Rio Grande do Sul, Rio Grande do Sul, Brazil. \\ 'Department of Genetics, Faculty of Veterinary, University of the Oriental Republic of Uruguay, Montevideo, Uruguay. \\ ${ }^{d}$ FEPAGRO Animal Health, Veterinary Research Institute Desidério Finamor, Rio Grande do Sul, Brazil. \\ ${ }^{\mathrm{e}}$ Molecular Microbiology Laboratory, Institute of Health Sciences, Feevale University, Rio Grande do Sul, Brazil
}

\begin{abstract}
RESUMEN
El presente estudio tuvo como objetivo detectar la presencia de BoHV-1 y BoHV-5 en infecciones latentes de ganado vacuno en el Uruguay. Se analizaron 62 muestras de ganglios trigéminos (TG) de cabezas de bovinos colectados en un frigorífico. Utilizando un tipo diferencial de PCR (nPCR) focalizando en el gen ULA4 de BoHV-1 y BoHV-5 se detectaron los diferentes genomas virales. ADN viral fue detectado en 64,5\% (40/62) de los animales. Treinta muestras $(48,4 \%)$ contenían solo el ADN de BoHV-1, mientras que nueve (14,5\%) contenían ADN de ambos BoHV-1 y BoHV-5. Una sola muestra (1,6\%) contenía apenas ADN de BoHV-5. La detección de anticuerpos neutralizantes se realizó en los sueros mediante la técnica de seroneutralización in vitro. Anticuerpos neutralizantes fueron encontrados en 16 de los animales portadores de ADN viral, lo que corresponde a $40 \%$ de las muestras con genoma viral identificado. La prevalencia genómica específica del tipo viral fue sustancialmente diferente de la que se informó en un estudio similar llevado a cabo en Brasil y puede estar asociada con el tipo de razas europeas predominante criadas en Uruguay, en contrapartida a los bovinos brasileños que son cruzados (Bos taurus x Bos indicus). Sin embargo, y a pesar de que tanto BoHV-1 y BoHV-5 pueden ser causas de coinfecciones ocasionales en Uruguay, BoHV-5 mostró una significativa menor prevalencia comparado con BoHV-1.
\end{abstract}

Palabras clave: BoHV-1, BoHV-5, nested PCR, Uruguay.

\section{SUMMARY}

The present study aimed to detect BoHV-1 and BoHV-5 latent infections in Uruguayan beef cattle. Trigeminal ganglia (TG) were collected from 62 cattle heads in a slaughterhouse. Viral genomes were detected by a type-differential nested PCR (nPCR) targeting the UL44 gene of BoHV-1 and BoHV5. Viral DNA was detected in 64.5\% (40/62) of the animals. Thirty cattle heads (48.4\%) contained only BoHV-1 DNA, whereas nine (14.5\%) contained DNA of both BoHV-1 and BoHV-5. One cattle head (1.6\%) contained BoHV-5 DNA only. Detection of neutralising antibodies was performed on sera of the examined cattle heads by a standard serum neutralization test. Neutralising antibodies were detected in 16 of the viral DNA-carrying animals, corresponding to $40 \%$ of the samples from which viral genomes were identified. The type-specific genomic prevalence was substantially different from that reported in a similar study carried out in Brazil and may be associated to the predominant European type of breeds farmed in Uruguay, as opposed to Brazilian cattle which is often crossbred (Bos Taurus x Bos indicus). Therefore, despite both BoHV-1 and BoHV-5 do circulate in Uruguay and sometimes both viruses can co-infect cattle, BoHV-5 infections seem less frequent than BoHV-1 infections.

Key words: BoHV-1, BoHV-5, nested PCR, Uruguay.

\section{INTRODUCTION}

Bovine herpesvirus type $1(\mathrm{BoHV}-1)$ and type 5 (BoHV-5) are members of the order Herpesvirales, family Herpesviridae, subfamily Alphaherpesvirinae (Davison et al 2009). Both viruses may be responsible for great losses to the cattle productive chain worldwide (Ackermann et al

Accepted: 04.12.2013.

\# CAPES, CNPq, FAPERGS and FINEP and CAPES.

* Av. Alberto Lasplaces 1620, Zip code 11.600, Montevideo, Uruguay; rpuentes@adinet.com.uy
1990; Engels and Ackermann 1996). Bovine herpesvirus 1 has been associated with respiratory tract infections (bovine infectious rinotracheitis, IBR), abortions, sporadic cases of encephalitis and reproductive tract infections (vulvovaginitis or balanopostitis) (Engels and Ackermann 1996, Muylkens et al 2007, Nandi et al 2009). Bovine herpesvirus 5 seems to be widely distributed in Latin America (Esteves et al 2008, Pidone et al 1999, Silva et al 2007), although it has been occasionally found in other regions of the world (Bartha et al 1969, Carrillo et al 1983, Diallo et al 2010, d'Offay et al 1993, Eugster et al 1975, Kirkland et al 2009). Bovine herpesvirus 5 has been associated with encephalitis and 
meningoencephalitis in calves and is of utmost importance in the differential diagnosis of bovine spongiform encephalitis (Meyer et al 2001). On occasions, BoHV-5 can also infect the genital tract of ruminants (Esteves et al 2003, Gomes et al 2003, Oliveira et al 2011).

In Uruguay, the serological prevalence of bovine herpesviruses (BoHV) in beef cattle was estimated in approximately $37 \%$, with $99 \%$ of the farms bearing animals with antibodies to either BoHV-1, BoHV-5, or both (Guarino et al 2008). However, these calculations were based on serological assays that do not allow differentiation between BoHV-1 and BoHV-5 infections, in view of the wide cross-reactivity observed with antibodies of naturally infected animals (Varela et al 2010). Consequently, the actual prevalence of infection with each virus type remains unknown. Therefore, the only precise way to differentiate BoHV-1 from BoHV-5 infections -as well as to identify co-infections- is to search for viral genomes, whose segments can then be sequenced and further analyzed to determine the virus type. The present study aimed to detect latently infected cattle by searching BoHV-1 and BoHV-5 DNA in trigeminal ganglia (TG) of beef cattle from slaughterhouses in Uruguay. In order to achieve that, a type-specific nested PCR (nPCR) was applied to allow distinction between both virus types. In addition, the frequencies of detection of viral DNA were compared to the results of serum neutralization $(\mathrm{SN})$, the standard serological test for detection of antibodies to BoHV.

\section{MATERIAL AND METHODS}

Blood samples and TGs were collected from 62 randomly chosen adult Hereford cows from 14 herds located in the south and east areas of Uruguay. The samples were obtained at the time of slaughtering in an abattoir located in Minas, Lavalleja, Uy. Blood samples were processed and sera stored at $-20{ }^{\circ} \mathrm{C}$. Cells of the lineage Madin-Darby bovine kidney (MDBK, originally from ATCC CCL 22) were used to multiply the Cooper strain of BoHV-1. The cells were kept in Eagle's minimal essential medium (EMEM, Gibco) supplemented fetal bovine serum (SFB, Cultilab) and antibiotics [10 IU/ml penicillin (Cultilab), 10 $\mathrm{mg} / \mathrm{ml}$ streptomycin (Cultilab) and $2 \mathrm{mg} / \mathrm{ml}$ amphotericin B (Cristalia)].

Trigeminal ganglia were collected in pairs as described (Campos et al. 2009). The TG were stored individually in 6-well plates and transported to the laboratory under refrigeration. Ganglia were then cut in several pieces, stored in wells of 24-well plates and frozen at $-80{ }^{\circ} \mathrm{C}$. All samples were carefully handled to avoid cross-contamination.

DNA was extracted from approximately $50 \mathrm{mg}$ of tissues of each TG as described previously (Campos et al 2009, Sambrook and Russel 2001). The recovered DNA was resuspended in $200 \mu \mathrm{l}$ of TE buffer $(10 \mathrm{mM}$ Tris $\mathrm{pH} 7.4 ; 1 \mathrm{mM}$ EDTA $\mathrm{pH} 8.0$ ). The quality and quantity of the extracted DNA was assessed by agarose gel electrophoresis.

Detection of BoHV-1 and BoHV-5 genomes was carried out with a PCR targeting a region on the $U L 44$ gene that codes for glycoprotein $\mathrm{C}$ ( $\mathrm{gC}$ ) as described by Esteves et al (2008). This non-type-discriminative reaction is expected to detect simultaneously BoHV-1 and BoHV-5. Type differentiation was achieved by a nPCR performed on the products of the first reaction, with type-specific primers as described previously (Campos et al 2009). In such assay, the primers targeting BoHV-1 DNA at an internal region of the $U L 44$ fragment amplified as above are expected to give rise to 161 base pairs (bp) product, whereas BoHV-5 primers are expected to amplify a $236 \mathrm{bp}-$ long amplicon. To avoid contamination with PCR products, separate rooms were used for extractions of ganglia DNA, to prepare the PCR reaction buffer, and to examine PCR products. Filter tips were used throughout; work benches were decontaminated with UV light and negative controls were included in every five PCR reactions. To confirm the specificity of the amplicons obtained, $12 \mathrm{nPCR}$ products were sequenced (Macrogen, Korea). The alignment of sequences was carried out using BioEdit v7.1.11 and the phylogenetic analysis was performed using MEGA 5.0 (Tamura et al 2011) by the Neighbor-Joining method (Saitou and Nei 1987). The evolutionary distances were computed using the Kimura 2-parameter method (Kimura 1980). Statistical significance of clades was measured by 500 bootstrap replicates (Felsenstein 1985).

To determine the serum prevalence of BoHV-1 and BoHV-5, sera of all 62 animals were tested using a 24-hour incubation serum neutralization test $(\mathrm{SN})$ as recommended (OIE 2010). Briefly, $50 \mu$ l of each serum were mixed with $50 \mu \mathrm{l}$ of $100 \mathrm{TCID}_{50}(50 \%$ tissue culture infectious dose) of BoHV-1. After a $24 \mathrm{~h}$ pre-incubation at $37^{\circ} \mathrm{C}, 100 \mu \mathrm{l}$ of a cell suspension ( $3 \times 10^{4}$ cells) were added per well and the plates incubated at $37{ }^{\circ} \mathrm{C}$ in a $5 \% \mathrm{CO}_{2}$ incubator. Five days later, titers were determined microscopically and calculated using the method of Reed and Muench (1938).

\section{RESULTS AND DISCUSSION}

The nested-PCR for UL44 gene of BoHV revealed that 40 out of the 62 sampled animals $(64.5 \%)$ contained genomes of at least one of the two herpesvirus types in TG. Bovine herpesvirus 1 DNA was detected in $30(48.4 \%)$ animals, whereas co-infections were detected in $9(14.5 \%)$ animals. BoHV-5 DNA was found in one sample (1.6\%).

Ten BoHV-5 and two BoHV-1 amplicons generated by nPCR, were sequenced to confirm the specificity of the analyses. Sequence alignment showed discrete exchange of nucleotides, suggesting that those were in fact distinct sequences and not PCR contamination (data not shown). Alignment of amino acid residues of BoHV-5 sequences showed two changes (positions 33 and 47 on figure 1a). Phylogenetic analyses grouped such sequences along 


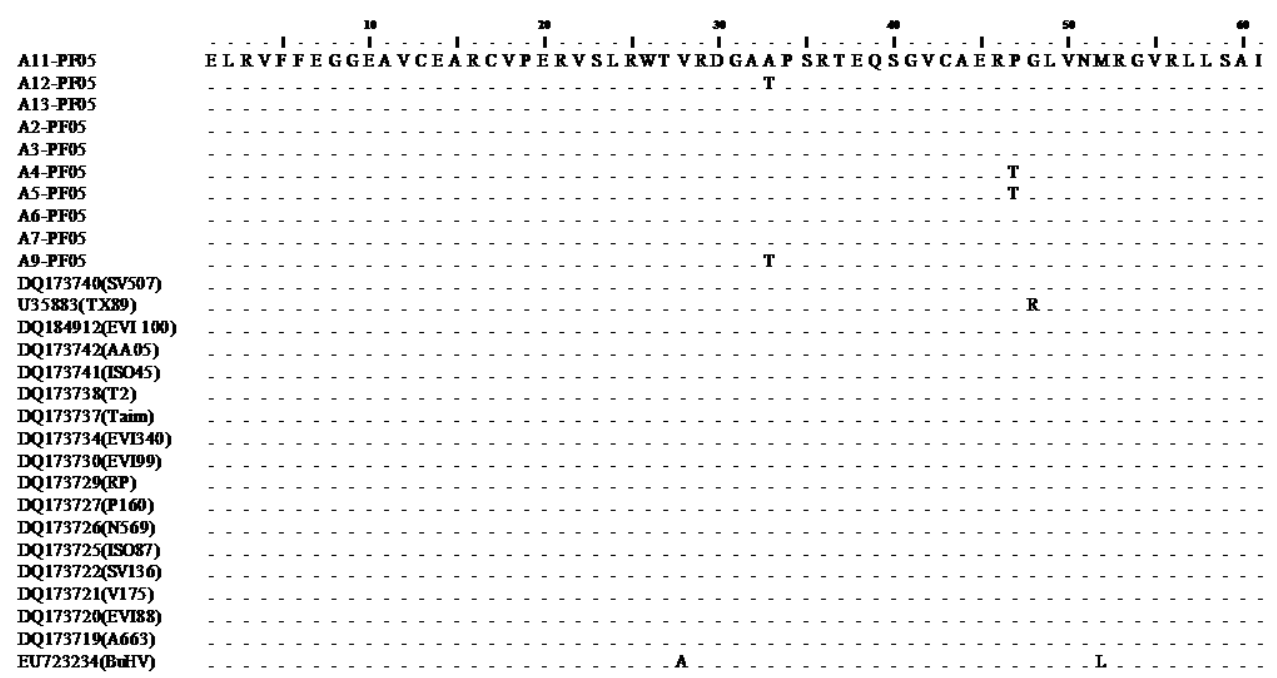

Figure 1a. Alignment of amino acid residues of BoHV-5 sequences using BioEdit v7.1.11 program. In total, 10 BoHV-5 sequences were aligned from this study, 17 BoHV-5 sequences and 1 BoHV-1 sequences were aligned from Genbank. Two changes are shown in position 33 (threonine by alanine, samples A12-PF05 and A9-PF05) and position 47 (threonine by proline, samples A4-PF05 and A5-PF05).

Alineamiento de secuencias de aminoácidos de BoHV-5 utilizando el programa BioEdit v7.1.11. En total se alinearon 10 secuencias de BoHV-5 de este estudio, 17 secuencias de BoHV-5 y 1 secuencia de BoHV-1 a partir de GenBank. Dos cambios se muestran en la posición 33 (treonina por alanina, las muestras A12-PF05 PF05-y A9) y la posición 47 (por treonina, prolina muestras A4 y A5-PF05-PF05).

with other BoHV-1 and BoHV-5 sequences available at GenBank (figure 1b). As all sequences generated were shorter than $200 \mathrm{bp}$, it was not possible to submit data to Genbank, as sequences shorter than 200 bp are not accepted for that purpose.

These findings confirm the circulation of BoHV-1 and, to a significantly lesser extent, BoHV-5, in Uruguayan cattle. It is interesting to compare such results with those of Campos et al (2009), who conducted a similar study in Brazil. There, the authors detected BoHV genomes in $87 \%$ of a sampled cattle population in an abattoir ( $n=200$ ), of which $82.8 \%$ had BoHV-1, 93.1\% had BoHV-5 and $75.9 \%$ had both BoHV-1 and BoHV-5 genomes, suggesting a higher prevalence of BoHV-5 than BoHV-1. In the present study, more animals were found infected with BoHV-1 than BoHV-5, with a relatively low number of co-infections. These highly significant differences in prevalence perhaps might be explained by the more restricted cattle management system adopted in Uruguay, where cattle imports are unusual and where zebu cattle (Bos indicus) is not usually mixed with European (Bos taurus) breeds; in Brazil, however, crossbreeding is fairly common and cattle from different regions of the country are frequently mixed with European breeds to improve resistance to heat and decrease susceptibility to ticks. Although to date there are no conclusive evidence to indicate that the source of BoHV-5 may be related to Bos indicus as the primary host species, the indirect evidence revealed by such differences in prevalence point towards some sort of participation of the species in BoHV-5 infection, as speculated previously (Studdert
1990). Such speculation, however, still requires sounder evidences before associations can be firmly drawn.

Serum neutralization tests revealed neutralizing antibodies to BoHV-1 in $25.8 \%$ (16/62) of the studied animals. In Uruguay, Repiso et al (2005) reported an overall serological prevalence of $36.6 \%$ in a study with more than 6,200 samples, revealing a highly scattered distribution of the infection. Other authors detected BoHV prevalence's ranging from $38 \%$ to $45 \%$ (Guarino et al 2008, Saizar 1997). It must also be highlighted that the neutralizing antibody prevalence in the sampled population was lower than the genomic prevalence determined by nPCR (overall genomic prevalence $64.5 \%$ ). In this case, just $40 \%$ of the infected population responded with detectable neutralizing antibodies. Campos et al (2009) detected $49.5 \%$ of the cattle examined with neutralizing antibodies over an $87 \%$ genomic prevalence, therefore, it seems clear that neutralizing antibodies are a much less sensitive indicator of BoHV infections than the genome search by the nPCR employed here. Thus, bearing the results reported here in mind, studies on prevalence must be interpreted with caution as a significant proportion of the infected population may be seronegative at the moment of testing. In view of the particular biology of herpesviruses, serology for BoHVs provides a rough estimate on the circulation of these viruses within a population, whereas prevalence as based on detection of BoHV-1 and BoHV-5 genomes is more precise than serological methods. Latently infected animals may present low titers of antibodies that may not be detected by all serological tests (Lemaire et al 2001). On the other side, the nPCR is a very sensitive technique, 


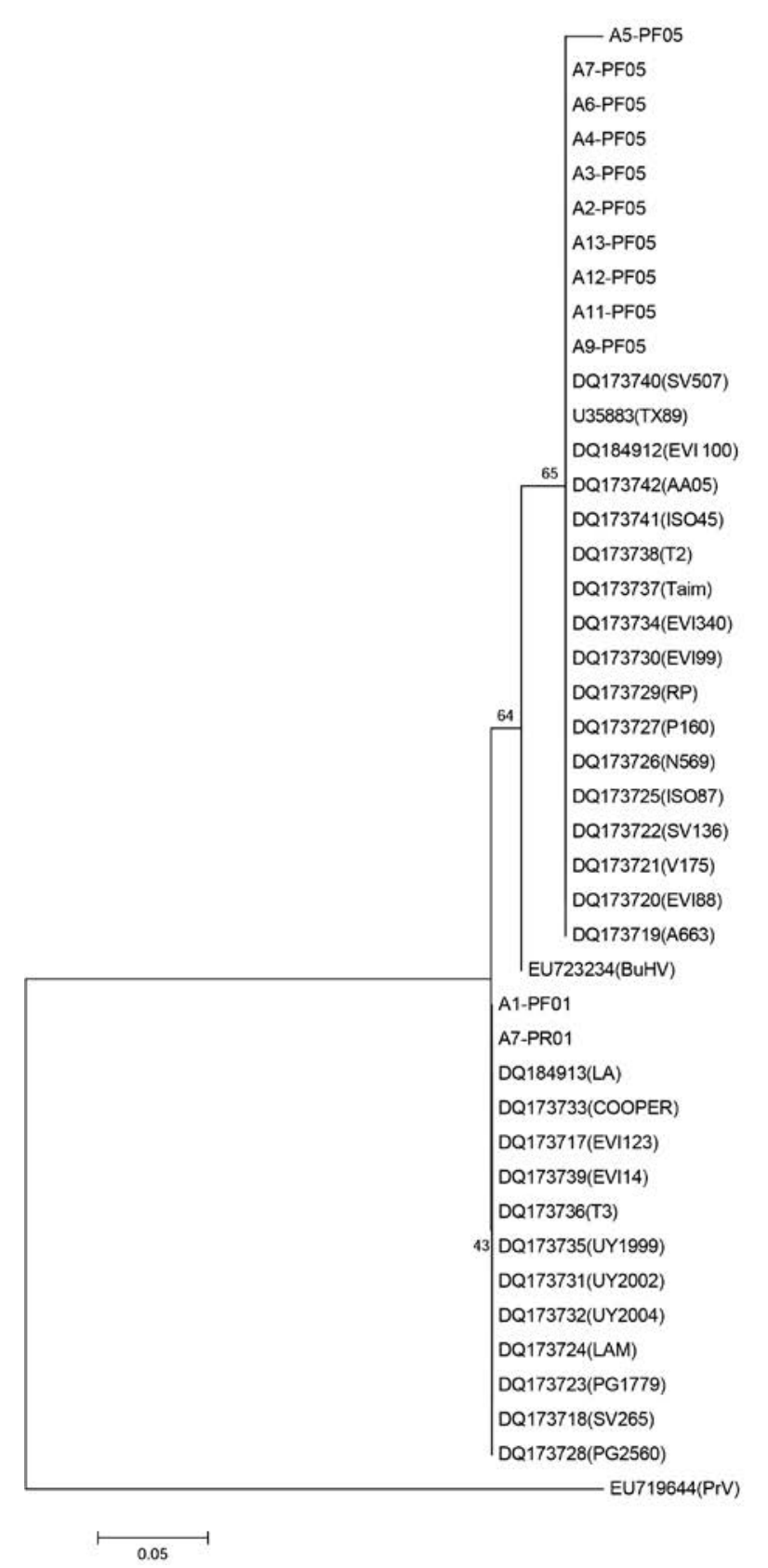

Figure 1b.Phylogenetic analysis of the partial UL44 gene sequences from BoHV-1 or BoHV-5 from nPCR positive samples and from GenBank (NCBI). In total, 10 BoHV-5 and 2 BoHV-1 sequences obtained in this study, 17 BoHV-5, 12 BoHV-1, 1 Bubaline Herpesvirus 1 (BuHV-1) and 1 Suid herpesvirus 1 (SuHV-1) sequence of Genbank were analyzed. The tree is drawn to scale, with branch lengths in the same units as those of the evolutionary distances used to infer the phylogenetic tree.

Análisis filogenético de las secuencias parciales del gen UL44 de BoHV-1 o BoHV-5 de muestras positivas por nPCR y del GenBank (NCBI). En total 10 secuencias de BoHV-5 y 2 de BoHV-1 obtenidas de este estudio, 17 de BoHV-5, 12 de BoHV-1, 1 de herpesvirus bubalino 1 (BuHV-1) y 1 de herpesvirus suine 1 (SuHV-1) obtenidas del GenBank, fueron analizadas. El árbol está diseñado a escala, con largos de rama en las mismas unidades que las distancias evolutivas utilizadas para inferir el árbol filogenético. capable of detecting a low number of DNA molecules per reaction (Campos et al 2009, Van Engelenburg et al 1995). However, access to TG requires slaughtering of cattle and this may be a major drawback in some instances. The sensitivity of the SN tests might have been increased by performing SNs against different challenge viruses. In a previous study, Varela et al (2010) detected about 30\% more seropositive samples by testing sera against at least four different BoHV-1 and BoHV-5 strains. Nevertheless, the sensitivity of the $\mathrm{SN}$ as a diagnostic tool in the present study would remain significantly lower than that of the nPCR.

The fact is that BoHV is never eliminated from an infected host and establishes life-long latency and may be reactivated at intervals. In recent years, a substantial increase in live cattle exports (beef and milk production) has occurred in Uruguay ${ }^{1}$. Simultaneously, in the Europe, a small number of countries have achieved IBR-eradication (Ackermann \& Engels, 2006). If BoHV becomes a new sanitary barrier in order to ensure live cattle export, Uruguay must be prepared to detect latent virus in tissues or samples of live animals, and this detection should be as efficient as nPCR technique presented here.

Using phylogenetic analyses, tree reconstruction provided a clear distinction between BoHV-1 and BoHV-5, as in the study of Traesel et al (2013), in which 41 BoHV isolates from Brazil, 2 of Uruguay and 2 of Argentina were compared.

This is the first report on the detection of BoHV-1 and BoHV-5 DNA in TG of beef cattle from Uruguay. The occurrence of BoHV-1 and BoHV-5 co-infections (Campos et al 2009), is also reported for the first time in the country. The genomic prevalence of BoHV infections seems higher than previously estimated by studies based on seroprevalence, yet quite different from the estimated type-specific prevalence reported in a study from southern Brazil, where BoHV-5 infections were found more prevalent than BoHV-1 infections (Campos et al 2009). Such difference is interesting and may be associated to the predominantly European type of breed in Uruguay, as opposed to Brazilian cattle which are often crossbred (Bos Taurus x Bos indicus). The findings on prevalence shall be more deeply examined in the future, as BoHV type-specific discrimination becomes more generally employed as a diagnostic method. It is expected that these findings will contribute significantly towards the understanding of the distribution of BoHVs in the country and in Latin America.

\section{ACKNOWLEDGEMENTS}

The authors would like to thank Frigorífico Arroyal S.A (Minas, Lavalleja) and special thanks to Dr. Susana Camaño for her support. P. M. Roehe, A. C. Franco and F. R. Spilki are CNPq research fellows. This work was financially supported by CAPES, CNPq, FAPERGS and FINEP.

1 www.mgap.gub.uy/portal/hgxpp001.aspx?7,5,208,O,S,0,MNU;E; 2;16;10;1;MNU. Accessed on 22 May 2013. 


\section{REFERENCES}

Ackermann M, HK Muller, L Bruckner, U Kihm. 1990. Eradication of infectious bovine rhinotracheitis in Switzerland: review and prospects. Vet Microbiol 23, 365-370.

Ackermann M, M Engels. 2006. Pro and contra IBR-eradication. Vet Microbiol 113, 293-302.

Bartha A, G Hajdu, P Aldasy, G Paczolay. 1969. Occurrence of encephalitis caused by infectious bovine rhinotracheitis virus in calves in Hungary. Acta Vet Acad Sci Hung 19, 145-151.

Campos FS, AC Franco, SO Hübner, MT Oliveira, AD Silva, PA Esteves, PM Roehe, FA Rijsewijk. 2009. High prevalence of co-infections with bovine herpesvirus 1 and 5 found in cattle in southern Brazil. Vet Microbiol 139, 67-73.

Carrillo BJ, A Ambrogi, AA Schudel, M Vazquez, E Dahme, A Pospischil. 1983. Meningoencephalitis caused by IBR virus in calves in Argentina. $J$ Vet Med B 30, 327-332.

d'Offay JM, RE Mock, RW Fulton. 1993. Isolation and characterization of encephalitic bovine herpesvirus type 1 isolates from cattle in North America. Am J Vet Res 54, 534-539.

Davison AJ, R Eberle, B Ehlers, GS Hayward, DJ McGeoch, AC Minson, PE Pellett, B Roizman, MJ Studdert, E Thiry. 2009. The Order Herpesvirales. Arch Virol 154, 171-177.

Diallo IS, GR Hewitson, J Hoad, S Turner, BG Corney, BJ Rodwell. 2010. Isolation of bovine herpesvirus type 5 from the semen of a healthy bull in Australia. Aus Vet $J$ 88, 93-95.

Engels M, M Ackermann. 1996. Pathogenesis of ruminant herpesvirus infections. Vet Microbiol 53, 3-15.

Esteves PA, FR Spilki, AC Franco, TC Silva, EA Oliveira, V Moojen, AM Esmeraldino, PM Roehe. 2003. Bovine herpesvirus type 5 in the semen of a bull not exhibiting clinical signs. Vet Rec 152, 658-659.

Esteves PA, OA Dellagostin, LS Pinto, AD Silva, FR Spilki, JR Ciacci-Zanella, SO Hübner, R Puentes, J Maisonnave, AC Franco, FA Rijsewijk, HB Batista, TF Teixeira, D Dezen, AP Oliveira, C David, CW Arns, PM Roehe. 2008. Phylogenetic comparison of the carboxy-terminal region of glycoprotein $\mathrm{C}(\mathrm{gC})$ of bovine herpesviruses (BoHV) 1.1, 1.2 and 5 from South America (SA). Virus Res 131, 16-22.

Eugster AK, AB Angulo, LP Jones. 1975. Herpesvirus encephalitis in range calves. $J$ Vet Diagn Invest 17, 267-281.

Felsenstein J. 1985. Confidence limits on phylogenies: An approach using the bootstrap. Evolution 39, 783-791.

Gomes LI, MA Rocha, JG Souza, EA Costa, EF Barbosa-Stancioli. 2003. Bovine herpesvirus 5 (BoHV-5) in bull semen: amplification and sequence analysis of the US4 gene. Vet Res Commun 27, 495-504.

Guarino H, A Núñez, MV Repiso, A Gil, DA Dargatz. 2008. Prevalence of serum antibodies tobovineherpesvirus- 1 and bovine viral diarrhea virus in beef cattle in Uruguay. Prev Vet Med 85, 34-40.

Kimura M. 1980. A simple method for estimating evolutionary rate of base substitutions through comparative studies of nucleotide sequences. J Mol Evol 16, 111-120.

Kirkland PD, AJ Poynting, X Gu, RJ Davis. 2009. Infertility and venereal disease in cattle inseminated with semen containing bovine herpesvirus type 5. Vet Rec 165, 111-113.

Lemaire M, F Schynts, G Meyer, JP Georgin, E Baranowski, A Gabriel, C Ros, S Belák, E Thiry. 2001. Latency and reactivation of a glycoprotein E negative bovine herpesvirus type 1 vaccine: influence of virus load and effect of specific maternal antibodies. Vaccine 19, 4795-4804.
Meyer G, M Lemaire, C Ros, K Belak, A Gabriel, D Cassart, F Coignoul, S Belak, E Thiry. 2001. Comparative pathogenesis of acute and latent infections of calves with bovine herpesvirus types 1 and 5 . Arch Virol 146, 633-652.

Muylkens B, J Thiry, P Kirten, F Schynts, E Thity. 2007. Bovine herpesvirus 1 infection and infectious bovine rhinotracheitis. Vet Res 38, 181-209.

Nandi S, M Kumar, M Manohar, RS Chauhan. 2009. Bovine herpes virus infections in cattle. Anim Health Res Rev 10, 85-98.

OIE, World Organization for Animal Health. 2010. Infectious bovine rhinotracheitis / infectious pustular vulvovaginitis. In: Manual of diagnostic tests and vaccines for terrestrial animals. OIE Terrestrial Manual. Chapter 2.4.13. Office international des epizooties, Paris, France, Pp 1-17.

Oliveira MT, FS Campos, MM Dias, FA Velho, GE Freneau, WM Brito, FA Rijsewijk, AC Franco, PM Roehe. 2011. Detection of bovine herpesvirus 1 and 5 in semen from Brazilian bulls. Theriogenology $75,1139-1145$.

Pidone CL, CM Galosi, MG Echeverria, EO Nosetto, ME Etcheverrigaray. 1999. Restriction endonuclease analysis of BHV-1 and BHV-5 strains isolated in Argentina. $J$ Vet Med B 46, 453-456.

Reed LJ, H Muench. 1938. A simple method of estimating fifty percent endpoints. Am J Hygiene 27, 493-497.

Repiso MV, A Gil, P Bañales, N D'Anatro, L Fernández, H Guarino, B Herrera, A Núñez, M Olivera, T Osawa, M Silva. 2005. Prevalencia de las principales enfermedades infecciosas que afectan el comportamiento reproductivo en la ganadería de carne y caracterización de los establecimientos de cría del Uruguay. Veterinaria (Montevideo) 40, 5-28.

Saitou N, M Nei. 1987. The neighbor-joining method: A new method for reconstructing phylogenetic trees. Mol Biol Evol 4, 406-425.

Saizar J. 1997. Determinación de la prevalencia de la Rinotraqueítis Bovina Infecciosa en rodeos de leche y carne en Uruguay. Veterinaria (Montevideo) 33, 133-136.

Sambrook J, DW Russell. 2001. Molecular cloning: a laboratory manual. $3^{\text {rd }}$ ed. Cold Spring Harbor Laboratory Press, Cold Spring Harbor, NY, USA.

Silva MS, MCS Brum, R Weiblen, EF Flores. 2007. Identificação e diferenciação de herpesvírus bovino tipos 1 e 5 isolados de amostras clinicas no Centro-Sul do Brasil, Argentina e Uruguai (1987-2006). Pesquisa Vet Bras 27, 403-408.

Studdert MJ. 1990. Bovine encephalitis herpesvirus. Vet Rec 126, 21-22.

Tamura K, D Peterson, N Peterson, G Stecher, M Nei, S Kumar. 2011. MEGA5: Molecular evolutionary genetics analysis using maximum likelihood, evolutionary distance, and maximum parsimony methods. Mol Biol Evol 28, 2731-2739.

Traesel CK, MS Silva, FR Spilki, R Weiblen, EF Flores. 2013. Nucleotide sequencing and phylogenetic analysis of the 3 region of glycoprotein $\mathrm{C}$ gene of South American bovine herpesviruses 1 and 5. Res Vet Sci $94,178-185$.

Van Engelenburg FA, FW Van Schie, FA Rijsewijk, JT Van Oirschot. 1995. Excretion of bovine herpesvirus 1 in semen is detected much longer by PCR than by virus isolation. J Clin Microbiol 33, 308-312.

Varela AP, CL Holz, SP Cibulski, TF Teixeira, DA Antunes, AC Franco, LR Roehe, MT Oliveira, FS Campos, D Dezen, A Cenci, WD Brito, PM Roehe. 2010. Neutralizing antibodies to bovine herpesvirus types 1 (BoHV-1) and 5 (BoHV-5) and its subtypes. Vet Microbiol $142,254-260$. 